\title{
Cassia occidentalis: effect on healing skin wounds induced by Bothrops moojeni in mice
}

\author{
Maraísa B. Delmut ${ }^{1 *}$, Leila M. L. Parente ${ }^{2 \dagger}{ }$, José R. Paula ${ }^{2 \dagger}$, Edemilsom C. Conceição ${ }^{2 \dagger}{ }^{\prime}$ Adriana S. Santos ${ }^{3 \dagger}$ and Irmantraut A. \\ H. Pfrimer ${ }^{4+}$ \\ *Correspondence: maraisadelmut@gmail.com \\ 'These authors are equally contributed to this work. \\ ${ }^{1}$ Federal University of Mato Grosso do Araguaia UFMT. Campus University (Campus II), BR-070, Km 5. Bar Herons, Mato \\ Grosso, MT, 78600-000, Brazil. \\ ${ }^{2}$ Research Laboratory of Natural Products, Pharmacy School, Federal University of Goiás, Av. Universitária, esq. com $1^{\text {a }}$ \\ Avenida, Setor Universitário, CEP: 74605-220, Goiâ-nia/GO - Brazil. \\ ${ }^{3}$ Department of Patology, Veterinary School, Federal University of Goiás, Campus Samambaia, Rodovia Goiânia-Nova \\ Veneza, Caixa Postal 131, CEP 74001-970, Goiânia/GO, Brazil. \\ ${ }^{4}$ Postgraduate in Environmental Science and Health, Catholic University of Goiás, Av. Universitária 1.440, Setor \\ Universitário, Goiânia-GO, CEP: 74605-010, Goiânia/GO, Brazil.
}

\begin{abstract}
Objective: To evaluate the healing activity of an extract from the leaves of Cassia occidentalis on skin wounds induced by the venom of Bothrops moojeni in mice.

Methods: A total of 24 Swiss albino mice were divided into 4 groups: Group 1 animals were treated for 7 days with lanette cream; Group 2 animals were treated for 7 days with 10\% leaf extract of Cassia occidentalis in lanette cream; Group 3 animals were treated for 14 days with lanette cream; and Group 4 animals were treated for 14 days with $10 \%$ leaf extract of Cassia occidentalis in lanette cream. To induce wounds, the animals were anesthetised intramuscularly after the dorsum cervical region was shaved and inoculated intradermally with $4 \mu \mathrm{g}$ Bothrops moojeni venom. The gross and histological evaluations were assessed 7 and 14 days after inoculation of the poison.

Results: Extract from the leaves of Cassia occidentalis decreased inflammation and epidermal hyperplasia and increased the vascular proliferation and reepithelialisation of wounds induced by Bothrops moojeni venom.

Conclusions: These data suggest that the leaves of Cassia occidentalis stimulated the healing of wounds induced by the dermal venom of Bothrops moojeni in mice, and they can be considered an alternative product to treat wounds caused by this snakebites.
\end{abstract}

Keywords: Medicinal plants, angiogenesis, bothrops

\section{Background}

The genus Bothrops is found in the Americas and is characterised by its adaptation to different types of environments. It is found in diverse ecosystems, even in flooded regions, and is responsible for the majority of snakebites in Brazil [1,2]. Bothrops moojeni is a species that has been attracting increased medical attention because its venom is composed of a complex mixture of proteins with biological activity, and it is used as a model to evaluate new drugs [3].

Snake bites can result in severe pain, oedema, bruising, redness and haemorrhagic blisters, which can progress to necrosis, which affects the skin, muscles and tendons [4] and is a major cause of loss of organ function.

Studies have been performed with various substances and therapies to minimise the local effects caused by Bothrops poisoning. Of these treatments, medicinal plants, such as Cassia occidentalis, are popularly used for snakebites [5].

C. occidentalis is an herbaceous species that is native to the Americans. It belongs to the family Fabaceae (Leguminosae) and subfamily Caesalpinioideae [6]. It is used in various traditional medicines for curing various diseases, with antibacterial, antifungal, anti-diabetic, anti-inflammatory, anticancer, antimutagenic, and hepatoprotective activities, and it has also been used to treat snakebites [7].

There are no data in the scientific literature on the action of medicinal plants on the side effects arising from snakebites. This study is aimed to evaluate the healing effect of extracts of leaves of Cassia occidentalis on skin wounds induced by the venom of Bothrops moojeni in mice.

\section{Methods}

Animals

Were 24 female Swiss albino mice, aged 60 days and

(C) 2013 Delmut et al; licensee Herbert Publications Ltd. This is an Open Access article distributed under the terms of Creative Commons Attribution License (http://creativecommons.org/licenses/by/3.0). This permits unrestricted use, distribution, and reproduction in any medium, provided the original work is properly cited. 
weighing 20 to $40 \mathrm{~g}$ from the Central Biotery of the UFG were used in the study.

The animals were acclimitisedated in the bioterium of the Centre of Studies and Research Toxic and Pharmacological (NEPET-UFG), Faculty of Pharmacy, UFG, for 15 days. They were kept in individual polyethylene cages lined with wood shavings under controlled environmental conditions (temperature $23 \pm 2{ }^{\circ} \mathrm{C}$, relative humidity between 50 and $70 \%$ and a $12 \mathrm{~h}$ light/dark photoperiod).Water and food were provided ad libitum. - The ethical principles in animal testing recommended by the Brazilian Society of Science in Laboratory Animals SBCAL - COBEA were follwed.

Collection of plant material and the preparation of extract from the leaves of Cassia occidentalis

The leaves of $C$. occidentalis were collected in the Goiânia region in December 2010 ( $15^{\circ} 01^{\prime} 11.8^{\prime \prime}$ south and $49^{\circ} 52$ $32.2^{\prime \prime}$ west) at an altitude of 756 meters.

The hydroalcoholic extract was obtained through percolation. - A glass percolator and $95 \%$ ethanol $(\mathrm{p} / \mathrm{v})$ was used as the extraction liquid. The process was monitored by the identification of glycosides anthraquinones with the Borntraeger reaction [8]. The extracts were concentrated with a rotary evaporator at a temperature below $40^{\circ} \mathrm{C}$ at a 1:4 ratio, resulting in extracts of the leaves (EF) of $C$. occidentalis.To obtain the herbal formulation, $10 \%$ of the extract from the leaves of $C$. occidentalis was incorporated into lanette cream (cream base) and packed in a plastic pot.

\section{Preparation of bothrops venom}

The crude venom of Bothrops moojeni was prepared according to the method proposed by [9]. The animals were intradermally inoculated with $4 \mu \mathrm{g}$ of venom diluted in 10 $\mathrm{ml}$ of saline applied $0.1 \mathrm{ml}$ in each mouse to cause necrosis with a $10 \mathrm{~mm}$ diameter. After 24 hours, the wound was treated with the topical application of $100 \mu \mathrm{L}$ of ethanolic extract in the treated group and $100 \mu \mathrm{L}$ of saline in case of untreated group.

\section{Experimental design}

The animals were weighed and randomly divided into four groups $(n=6)$ :

Group 1 - the animals were treated for seven days with lanette cream.

Group 2 - the animals were treated for seven days with lanette cream containing $10 \%$ of the leaf extract of $C$. occidentalis in (EF).

Group 3 - the animals were treated for fourteen days with lanette cream.

Group 4 - the animals were treated for fourteen days with lanette cream containing $10 \%$ of the leaf extract of C. occidentalis (EF).

\section{Wound induction}

To induce the wound, the animals were anesthetised intramuscularly with a decloridrato combination of ketamine $\left(70 \mathrm{mg} \mathrm{kg}^{-1}\right)$ and xylazine $\left(10 \mathrm{mg} \mathrm{kg}^{-1}\right)$. After shaving the dorsal neck region, the mice were inoculated intradermally with $4 \mu \mathrm{g}$ B. moojeni venom. Paracetamol was administered orally as an analgesic, and the dose was calculated by allometry. After 24 hours, topical treatments were initiated and performed daily at the same time.

\section{Wound evaluation}

Wound induction and treatment was performed without complications. There was no complication in relation to anaesthesia and the animals demonstrated good general motor activity and normal behaviour for the species after the procedures.

All animals were examined daily for general appearance. Besides, macroscopic evaluation was done through daily observation of the wound, and the data was recorded individually.

\section{Euthanasia of animals}

At the end of the experiment, the animals were weighed and euthanised by anaesthesia with a combination of ketamine hydrochloride (100 $\left.\mathrm{mg} \mathrm{kg}^{-1}\right)$ and xylazine hydrochloride $\left(30 \mathrm{mg} \mathrm{kg}^{-1}\right)$.

\section{Histological evaluation}

For histological evaluation, a fragment of each wound was removed, fixed in $10 \%$ formalin, and processed and stained with haematoxylin and eosin (HE).

The histological examination was conducted by the Division of Pathology, Veterinary School, Federal University of Goiás (Brazil). The following variables were evaluated on day 7: fibrin, haemorrhage, oedema, hyperaemia, inflammatory infiltration of polymorphonuclear cells, the infiltration of fibroblasts and vascular proliferation. On day 14 , the following parameters were evaluated: reepithelialisation, epithelial hyperplasia, collagen, vascular proliferation and inflammatory infiltrates. Adapted scores were used [10].

\section{Statistical analysis}

The results were submitted to statistical treatment by the use of GraphPad InStat software (Version 3.05 for Windows). From the Kolmogorov-Smirnov test for normality, histological analysis data were performed a semi-quantitative assessment using the Kruskal-Wallis test, and the least significant differences were determined using the Dunn test. The statistics were considered significant when the $p$ value was less than $0.05(p<0.05)$.

\section{Results \\ Animal weights}

The results pertaining to the weight of the animals at the beginning and end of the assessment period are shown in Table 1. All of the experimental groups showed a decrease 
Delmut et al. Journal of Pharmaceutical Technology \& Drug Research 2013, http://www.hoajonline.com/journals/pdf/2050-120X-2-10.pdf

doi: 10.7243/2050-120X-2-10

Table 1. The average weight of the animals at the beginning and end of the evaluation period ( 7 and 14 days after the inoculation of Bothrops moojeni venom).

\begin{tabular}{cccc}
\hline \multicolumn{4}{c}{ Average of Weights $(\mathrm{g})$} \\
\hline Groups & Initial & Final & Final averages \\
\hline Group 1 & 30,66 & 27,66 & 28,44 \\
Group 2 & 30,33 & 28,33 & 31,39 \\
Group 3 & 30,83 & 29,33 & 30,22 \\
Group 4 & 32,16 & 28,50 & 29,22 \\
\hline
\end{tabular}

Group 1 - animals treated for seven days with lanette cream. Group 2 - animals treated for seven days with lanette cream with $10 \%$ leaf extract of $\mathrm{C}$. occidentalis (EF).

Group 3 - animals treated for fourteen days with lanette cream. Group 4 - animals treated for fourteen days with lanette cream with $10 \%$ leaf extract of C. occidentalis (EF).

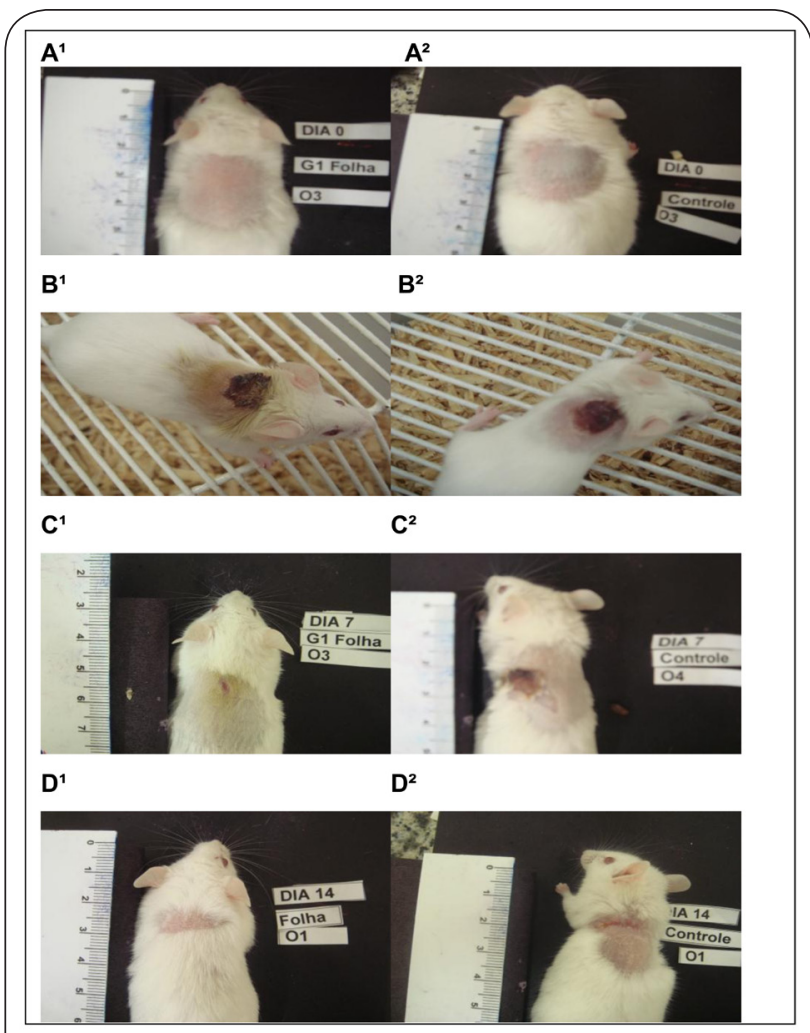

Figure 1. A-After inoculation with B. moojeni poison; B - 3 days following the inoculation of mice with B. moojeni venom and treatment with ${ }^{1} 10 \%$ leaf extract of Cassia occidentalis in lanette cream (EF) or ${ }^{2}$ lanette cream only (not untreated); C - 7 days after the inoculation of mice with $B$. moojeni venom and treatment with ${ }^{1} 10 \%$ leaf extract of Cassia occidentalis in lanette cream (EF) or ${ }^{2}$ lanette cream only (not untreated); D - 14 days after the inoculation of mice with B. moojeni venom and treatment with ${ }^{1} 10 \%$ leaf extract of Cassia occidentalis in lanette cream (EF) or ${ }^{2}$ lanette cream only (not untreated).
Table 2. Median histological variables evaluated at day 7 after the inoculation of Bothrops moojeni venom in mice treated with $10 \%$ of leaf extracts of Cassia occidentalis in lanette cream (EF).

\begin{tabular}{lccc}
\hline Histological variables & \multicolumn{2}{c}{ Lanette cream } & $P$ \\
\hline & C. occidentalis (-) & C. occidentalis $(+)$ & \\
\hline Necrosis & $3,0^{\mathrm{a}}$ & $3,0^{\mathrm{a}}$ & 0,28 \\
Oedema & $0,0^{\mathrm{a}}$ & $0,0^{\mathrm{a}}$ & 0,44 \\
Hyperaemia & $1,0^{\mathrm{a}}$ & $1,0^{\mathrm{a}}$ & 0,26 \\
Haemorrhage & $3,0^{\mathrm{a}}$ & $3,0^{\mathrm{a}}$ & 0,43 \\
polymorphonuclear & $2,5^{\mathrm{a}}$ & $3,0^{\mathrm{a}}$ & 0,14 \\
inflammatory infiltrate & & $1,0^{\mathrm{a}}$ & 0,12 \\
Infiltration of fibroblasts & $2,0^{\mathrm{a}}$ & $2,0^{\mathrm{b}}$ & $0,032^{\star}$ \\
Vascular proliferation & $1,0^{\mathrm{a}}$ &
\end{tabular}

( $\mathrm{p}=$ level of significance. Different letters differ significantly

(Kruskal-Wallis, Dunn's post-test, ${ }^{*} \mathrm{p}<0.05$ )

(-) Without plant extract

(+) With plant extract

Table 3. Median histological variables assessed at day 14 after the inoculation of Bothrops moojeni venom in mice treated with $10 \%$ of the extract of leaves of Cassia occidentalis in Lanette cream (EF).

\begin{tabular}{lccc}
\hline Histological variables & Not treated & Treated with EF & $\boldsymbol{P}$ \\
\hline Collagen & $2,0^{\mathrm{a}}$ & $2,0^{\mathrm{a}}$ & 0,57 \\
Inflammatory infiltrate & $2,0^{\mathrm{a}}$ & $2,0^{\mathrm{a}}$ & 0,50 \\
Vascular proliferation & $1,0^{\mathrm{a}}$ & $2,0^{\mathrm{b}}$ & $0,045^{*}$ \\
\hline
\end{tabular}

$\overline{(p=\text { level of significance. Different letters differ significantly }}$ (Kruskal-Wallis, Dunn's post-test, ${ }^{\star} \mathrm{p}<0.05$ ).

in the final weight.

\section{Macroscopic analysis}

In the macroscopic analysis, the wounds treated with leaf extract were dry, thinner and had few signs of inflammation on the 3rd day, and they disappeared on the 6th day after inoculation of the poison (Figure 1). In the groups that were not treated with the plant extract, the wounds appeared red. On the 3rd day, the animals showed a reaction of pain to the touch, and the wounds only disappeared on the 9th day after inoculation of the poison (Figure 1).

Area of skin wounds decreased during the healing process. In mice treated with the plant extract, all wounds were completely healed on the 14th day after inoculation of the poison. In mice not treated with the plant extract, only $60 \%$ of the animals showed complete healing on the 14th day (Figure 1).

The macroscopic evaluation of wounds in animals treated with leaf extracts revealed that $100 \%$ of the mice showed complete reepithelialisation of wounds on 14th day. In Mice not treated with plant extract, partial reepithelialisation was observed. $40 \%$ of the animals had open wounds even on the 14th day after inoculation of the poison (Figure 1).

\section{Microscopic analysis}

Results of histological analyses are presented in 
Table 4. Median ( $\mathrm{mm}$ ) epidermal hyperplasia at 14 days after the inoculation of Bothrops moojeni venom in mice treated with $10 \%$ of the extract of leaves of Cassia occidentalis in Lanette cream (EF).

\begin{tabular}{lc}
\hline Groups & Hyperplasia \\
\hline Lanette without EF & $86,41^{\mathrm{a}}$ \\
Lanette with EF & $69,04^{\mathrm{b}}$ \\
$\boldsymbol{P}$ & $0,0076^{*}$ \\
\hline
\end{tabular}
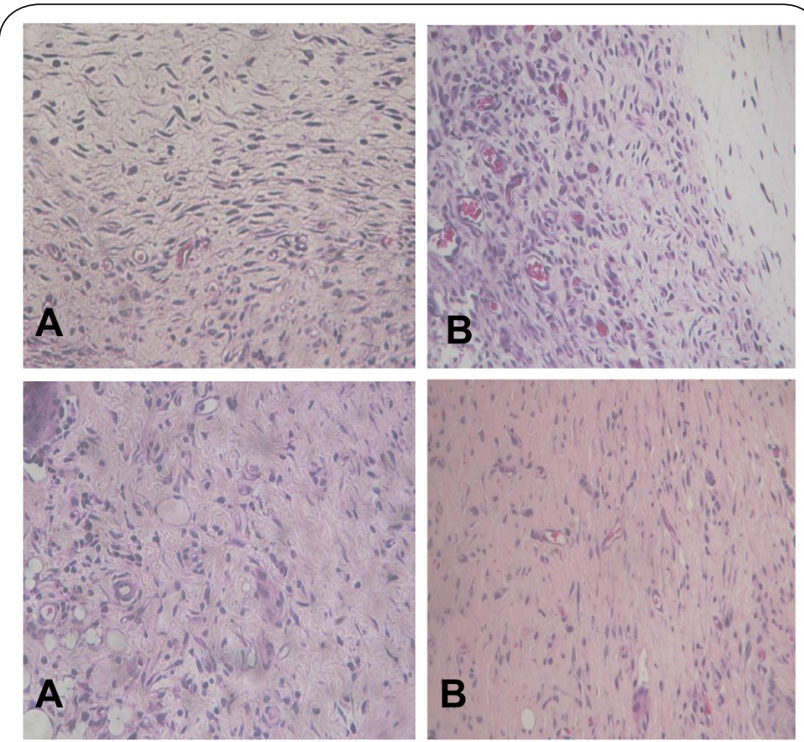

Figure 2. Photomicrographs of the skin wounds in mice at 7 (A) and 14 (B) days postoperatively demonstrating the presence of blood vessels. A1 and A2 are control mice, and $\mathbf{B} 1$ and $\mathbf{B} 2$ are mice treated with lanette cream with $10 \%$ leaf extract of Cassia occidentalis. Haematoxylin-eosin. 20x.

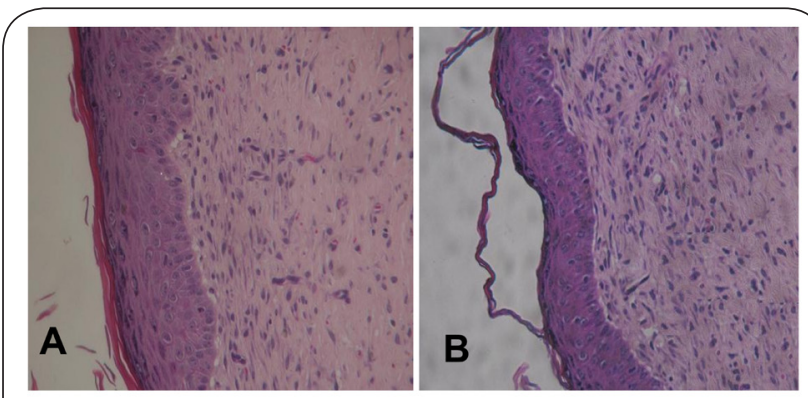

Figure 3. Photomicrograph of mouse skin wound showing epidermal hyperplasia. Group not treated with Cassia occidentalis (A1) and group treated with lanette cream with $10 \%$ leaf extract of Cassia occidentalis (B1) on the 14th day postoperatively. Haematoxylin-eosin. 20x.

Tables 2, 3 and $\mathbf{4}$ and Figures $\mathbf{2}$ and 3. In mice treated with plant extract, regardless of the time of treatment (7 or 14 days), a significant increase in vascular proliferation (Tables 2 and $\mathbf{3}$ and Figure 2) was observed. A significant reduction in epidermal hyperplasia was observed on 14th day in the animals treated with leaf extracts of $C$. occidentalis compared to the mice not treated with plant extracts (Table 4 and Figure 3).

\section{Discussion}

In this study it was observed that leaf extract of $C$. occidentalis decreased inflammatory processes and epidermal hyperplasia and increased vascular proliferation and the reepithelialisation of wounds induced by Bothrops moojeni in mice.

Bothrops snake bites are an important public health problem in tropical regions around the world. The local reaction caused by bothropic venom has been the focus of several investigations. The use of substances with the therapeutic potential of minimising these reactions has been studied, with medicinal plant, such as C. occidentalis, which is popularly used for snakebites [11].

From this work, it is clear that the cutaneous wounds of the animals in the mice treated with plant extract were dry and had few signs of inflammation. Scientific studies have shown that Cassia occidentalis has an enormous biological potential and may have anti-inflammatory, antiplatelet, muscle relaxant, and anti-haemolytic activities and inhibit lipid peroxidation. These effects may occur probably as it is rich in derivativeslike anthraquinônes [5].

The reduction in epidermal hyperplasia observed in the groups treated with plant extract may be associated with a positive effect of $C$. occidentalis on the inflammatory phase. Moreover, the venom of snakes of the genus Bothrops has high proteolytic activity, which is responsible for the primary characteristic systemic effects observed after snakebites [12].

Wound healing occurs in overlapping and interdependent phases [13], including inflammation, repair, and maturation. Many processes occur during the proliferative phase of wound repair, including angiogenesis, fibroplasia and epithelialisation [14], highlighting that angiogenesis is one of the most important histological features in the granulation tissue in the healing process of the skin [15]. In this study, animals treated with plant extract showed complete epithelialisation and angiogenesis on the 7th and 14th day after wound induction by poison.

Angiogenesis is the growth or formation of new blood vessels from pre-existing vessels at the ends of the wound that were previously devoid of blood vessels [16]. One way to enhance the healing process is to stimulate angiogenesis, which can be established by removing debris and supplying essential nutrients and oxygen to the wound site. The results of this study corroborate other studies $[10,17,18,19,20]$. Similar effects have been observed in the study, which justifies the macroscopic findings of the best resolution of the healing process.

The microscopic analyses revealed a decrease in epidermal hyperplasia on the 14th day in the group treated with the extract of leaves of $C$. occidentalis. Hyperplasia corresponds to the increased cellularity of a tissue due to a higher functional demand or hyperstimulation [21]. During 
the inflammatory process, hyperplasia can occur through phenomena that are intrinsic to inflammation, such as hyperaemia and the synthesis of substances that stimulate cell division. Thus, the more intense and long-lasting the inflammatory response, the greater the hyperplastic response of the cells involved in the process [22].

During the healing process, when there is a delay in the elimination of the initial cause of the lesion by the inflammatory response, there is a higher number of hyperplastic cells [23], and leaf extracts of $C$. occidentalis can act to minimise the inflammatory effects of Bothrops moojeni poison and accelerate the healing process.

\section{Conclusion}

These data suggest that extract of leaves of $C$. occidentalis stimulate the healing of wounds induced by the venom of B. moojeni in mice, and it can be considered an alternative product to treat snakebite wounds.

\section{List of abbreviations \\ C. occidentalis: Cassia occidentalis \\ B. moojeni: Bothrops moojeni \\ HE: haematoxylin and eosin \\ EF: leaf extract of $C$. occidentalis}

\section{Competing interests}

The authors declare that they have no competing interests.

\section{Authors' contributions}

MBD planning and execution of all the experimental stage, tabulation and analysis of data and writting of the manuscript. LMLP experimental design, planning and execution of all the experimental stage, and tabulation and analysis of data and writing of the manuscript. JRP collection and identified the plants species and analysis of extract. EMC cream preparation for the experiment. ASS microscopic analysis. IAHP orientation, experimental design and writing of the manuscript.

Acknowledgement

We are grateful to Dr. Adenilda Cristina Honorio-

França and Dr. Eduardo Luzia França (UFMT/ICBS/

(UA), for helpful suggestions of this manuscript.

Publication history

Received: 09-Nov-2012 Revised: 09-Jan-2013

Accepted: 08-Feb-2013 Published: 25-Feb-2013

\section{References}

1. Diefenbach A, Anjos BL, Caldas SA, Peixoto TC, Brito MF, Yamasaki EM, Rita PHS, Tokarnia CH: Aspectos clinicopatológicos e laboratoriais do envenenamento experimental por Bothrops moojeni e Bothropoides neuwiedi em ovinos.Pesq. Vet. Bras 2012, 32: 49-60. | Article

2. Dutra NC, Telles MP, Dutra DL and Silva Junior NJ: Genetic diversity in populations of the viper Bothrops moojeni Hoge, 1966 in Central Brazil using RAPD markers. Genet Mol Res 2008, 7:603-13. | Pdf | PubMed

3. Queiroz MR, Mamede CC, Fonseca KC, Canabrava LCMN, França LV, Silva MC, Stanziola L, Beletti ME, Canabrava HAN, Oliveira F: Biological characterization of a myotoxin phosphoplipase $A 2$ homologue purified from the venom of the snake Bothrops moojeni.The Journal of Venomous Animals and Toxins including Tropical Diseases 2011,
17:49-58. I Pdf

4. Nadur-Andrade N, Barbosa AM, Carlos FP, Lima CJ, Cogo JC and Zamuner SR: Effects of photobiostimulation on edema and hemorrhage induced by Bothrops moojeni venom. Lasers Med Sci 2012, 27:65-70. | Article | PubMed

5. Yadava RN, Satnami DK: Chemical constituents from Cassia occidentalis Linn. Indian Journal of Chemistry 2011, 50B:1112-1118. I Pdf

6. Silva MG, Aragao TP, Vasconcelos CF, Ferreira PA, Andrade BA, Costa IM, Costa-Silva JH, Wanderley AG and Lafayette SS: Acute and subacute toxicity of Cassia occidentalis L. stem and leaf in Wistar rats. J Ethnopharmacol 2011, 136:341-6. I Article I PubMed

7. Yadav JP, Arya V, Yadav S, Panghal M, Kumar S and Dhankhar S: Cassia occidentalis L.: a review on its ethnobotany, phytochemical and pharmacological profile. Fitoterapia 2010, 81:223-30. | Article | PubMed

8. Uphof,J.C.T. Plant Hairs.Berlin:Gebrueder Borntraeger;1962. | Article | PubMed Abstract | PubMed Full Text

9. Theakston RD and Reid HA: Development of simple standard assay procedures for the characterization of snake venom. Bull World Health Organ 1983, 61:949-56. | Article | PubMed Abstract | PubMed Full Text

10. Parente LML, Silva MSB, Brito LAB, Lino-Júnior RS, Tresvenzol LMF, Zatta DT, Paulo NM: Efeito cicatrizante e atividade antibacteriana da Calendula officinalis L. cultivada no Brasil. Revista Brasileira de Plantas Medicinais 2009, 11:383-391. I Article

11. Aragao TP, Lyra MM, Silva MG, Andrade BA, Ferreira PA, Ortega LF, da Silva SD, da Silva JC, Fraga MC, Wanderley AG and Lafayette SS: Toxicological reproductive study of Cassia occidentalis $L$. in female Wistar rats. J Ethnopharmacol 2009, 123:163-6. | Article | PubMed

12. Salvador GH, Marchi-Salvador DP, Silveira LB, Soares AM and Fontes MR: Crystallization and preliminary $X$-ray diffraction studies of BmooPLA2-I, a platelet-aggregation inhibitor and hypotensive phospholipase A2 from Bothrops moojeni venom. Acta Crystallogr Sect F Struct Biol Cryst Commun 2011, 67:900-2. | Article | PubMed

13. Timaru-Kast R, Luh C, Gotthardt P, Huang C, Schafer MK, Engelhard K and Thal SC: Influence of age on brain edema formation, secondary brain damage and inflammatory response after brain trauma in mice. PLoS One 2012, 7:e43829. | Article | PubMed Abstract | PubMed Full Text

14. Hofmann NA, Ortner A, Jacamo RO, Reinisch A, Schallmoser K, Rohban R, Etchart N, Fruehwirth M, Beham-Schmid C, Andreeff M and Strunk D: Oxygen sensing mesenchymal progenitors promote neovasculogenesis in a humanized mouse model in vivo. PLoS One 2012, 7:e44468. | Article | PubMed Abstract | PubMed Full Text

15. Liew SC, Das-Gupta E, Chakravarthi S, Wong SF, Lee N, Safdar N and Jamil A: Differential expression of the angiogenesis growth factors in psoriasis vulgaris. BMC Res Notes 2012, 5:201. I Article I PubMed Abstract | PubMed Full Text

16. Okazaki H, Hirakawa S, Shudou M, Nakaoka Y, Shirakata Y, Miyata $\mathrm{K}$, Oike $\mathrm{Y}$, Hashimoto $\mathrm{K}$ and Sayama K: Targeted overexpression of Angptl6/angiopoietin-related growth factor in the skin promotes angiogenesis and lymphatic vessel enlargement in response to ultraviolet B. J Dermatol 2012, 39:366-74. | Article | PubMed

17. Honorio-Franca AC, Marins CM, Boldrini F and Franca EL: Evaluation of hypoglicemic activity and healing of extract from amongst bark of "Quina do Cerrado" (Strychnos pseudoquina ST. HILL). Acta Cir Bras 2008, 23:504-10. | Article | PubMed

18. Sheeba M, Emmanuel S, Revathi K, Ignacimuthu S: Wound healing activity of Cassia occidentalis L. in albino Wistar rats. International Journal of Integrative Biology 2009, 8:1-6. | Pdf

19. Vale LH, Mendes MM, Hamaguchi A, Soares AM, Rodrigues VM and Homsi-Brandeburgo MI: Neutralization of pharmacological and toxic activities of bothrops snake venoms by Schizolobium parahyba (Fabaceae) aqueous extract and its fractions. Basic Clin Pharmacol Toxicol 2008, 103:104-7. | Article | PubMed

20. Yusufoglu HS, Alqassoumi SI: Anti-inflammatory and Wound Healing Activities of Herbal Gel Containing an Antioxidant Tamarix aphylla Leaf Extract. Int.J.Pharmacol 2011, 7: 829-835. | Pdf

21. Franco M, Montenegro MR, Brito T, Bacchi CE, Almeida PC: Patologia processos gerais.Atheneu, São Paulo 2010.

22. Zhang Q, Wei F, Fong CC, Yu WK, Chen Y, Koon CM, Lau KM, Leung PC, Lau CB, Fung KP and Yang M: Transcriptional profiling of human skin 
Delmut et al. Journal of Pharmaceutical Technology \& Drug Research 2013, http://www.hoajonline.com/journals/pdf/2050-120X-2-10.pdf

fibroblast cell line Hs27 induced by herbal formula Astragali Radix and Rehmanniae Radix. J Ethnopharmacol 2011, 138:668-75. I

Article | PubMed

23. Ashkani-Esfahani S, Imanieh MH, Khoshneviszadeh M, Meshksar A, Noorafshan A, Geramizadeh B, Ebrahimi S, Handjani F and Tanideh $\mathrm{N}$ : The healing effect of arnebia euchroma in second degree burn wounds in rat as an animal model. Iran Red Crescent Med J 2012, 14:70-4. | PubMed Abstract | PubMed Full Text

\section{Citation:}

Delmut M B, Parente L M, Paula J R, Conceição E C, Santos A S and Pfrimer I A H: Cassia occidentalis: effect on healing skin wounds induced by Bothrops moojeni in mice. journal of Pharmaceutical

Technology and Drug Research 2013, 2:10. http://dx.doi.org/10.7243/2050-120X-2-10 